\title{
Radon and Radium Determination in Coffee Using CR-39 Nuclear Track Detector
}

\author{
Yasser H. Al- Mashhadani Khalid A. Jassim Hayfa A .Al-Sawaf \\ Department of Physics \\ College of Science \\ Mosul University
}

(Received 2/ 7/ 2008 ; Accepted 26/1/2009)

\begin{abstract}
Radon $\left({ }^{222} \mathbf{R n}\right)$ concentration and Radium $\left({ }^{226} \mathbf{R a}\right)$ content in some selected samples of Coffee powder of common use collected from the market, were estimated using solid state nuclear track detectors $\mathbf{C R}-\mathbf{3 9}$. The Radon gas concentration was found to vary from ( 36-108)Bq. ${ }^{-3}$. The effective Radium content of solid samples varies from ( $0.0185-0.0925)$ Bq. $\mathrm{kg}^{-1}$. The present investigation is useful from the health and environmental point of view.

\section{مسلب تركيز الرالهن والراليوم في نماذجمختارةمن البن بالستخدلمكلف الثر \\ CR - 39}

\section{الملغص}

قم في هذا البمث ققدير تركيز غاز الرادون ومحتوى الراديوم في بعض النماذج المختارة من مـ الة

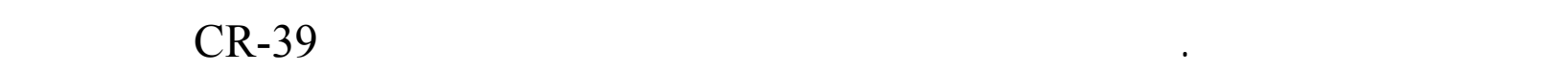

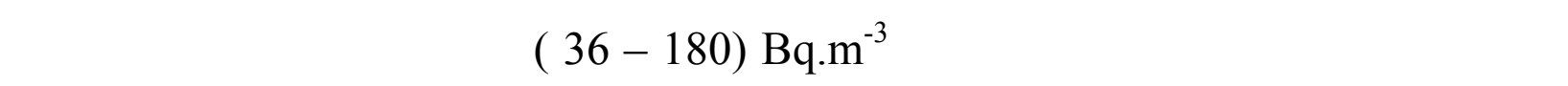

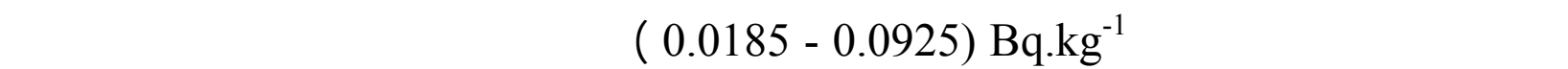

الصحية والبيئية .
\end{abstract}

\section{INTRODUCTION}

Radon is a gas heavier than air and is called (radium emanation ). Since radon, is a colorless, odorless, tasteless and invisible radioactive gas, therefore suitable detectors should be used to detect its presence.

Radon-222 is a natural radioactive gas comes from the decay of radium -226 in the uranium-238 series. Radium is distributed in soil rocks ,ocean waters and sediments. 
As radon atoms decay they emit alpha particles with $5.486 \mathrm{MeV}$ of energy, to produce a polonium isotopes (Po- 218 and Po-214 )(Kaplan,1963).

Naom,2002, has measured radon and radium contents in different samples of tooth pastes using CR-39 plastic nuclear track detector. The study showed that the radon content approached to(0.094-0.429) $\mathrm{Bq}^{-\mathrm{kg}^{-1}}$ The radon content has also determined in different samples of imported tea by (Al-Gibourie ,1999) results reveal that radon content ranged between about (24-51) Bq. $\mathrm{m}^{-3}$.

Radium isotope naturally occurring in the environment may be up take by different plants and trees, which consumed by human beings, therefore we decided to estimate the radium content in coffee samples of common use collected from the local market. The work is also important from the view points of health and environmental problems.

\section{EXPERIMENTAL PROCEDURE}

The radium Content can be obtained from measuring the $\alpha$-particles emitted from radon-222 and its daughters using the solid state nuclear track detector ( SSNTD ) CR-39. The test tube technique was adopted to measure the $\alpha$-particle emitted from the sample.

Sheets of CR - 39 detectors were cut into pieces square in shape ( $1 \mathrm{~cm} \mathrm{x} 1 \mathrm{~cm}$ ) and mounted on the inner top side of rubber enclosure.

The radius of the tube and air space between the detector and coffee sample were $(0.925 \mathrm{~cm})$ and $(4 \mathrm{~cm})$ respectively. This is in agreement with the recommended values given by ( Nikezie et al., 1996), which gives small uncertainty in radon measurements. The whole system was sealed for (65 days) .

After exposure, the detectors were removed and etched in $(6.25 \mathrm{NaoH})$ solution at $\left(70{ }^{\circ} \mathrm{C}\right)$ for $(4 \mathrm{hrs})$. The through - etched holes produced by the $\alpha$-particles were counted using an optical microscope with a magnification of $(40 \mathrm{X})$. More information can be seen elsewhere (Khalil and Abdul - Maseeh, 2001 ).

Since the half-life of Ra-226 is (1620 year)and that of Rn-222 is (3.82days), it is reasonable to assume that an effective equilibrium(about 98\%) for radium radon members of the decay series is reached in by about (3)weeks time (Azam et al.,1995).

\section{RADON AND RADIUM ESTIMATION}

The Track density $\boldsymbol{\rho}$ (tracks . $\mathrm{cm}^{-2}$ ) is related to the radon activity concentration $\boldsymbol{C}_{\mathbf{R n}}$ $\left(\mathrm{Bq} \cdot \mathrm{cm}^{-3}\right)$ and the exposure time $\mathrm{T}$ (days) by the formula (Azam et al ., 1995 ):

$$
\mathrm{C}_{\text {Rn }}\left(\mathrm{Bq} . \mathrm{cm}^{-3}\right)=\frac{\rho}{\mathrm{K} . \mathrm{T}}
$$

Where $\mathrm{K}$ is the sensitivity factor in $\mathrm{cm}$ and is given by :

$$
\begin{aligned}
& K=\frac{1}{4}\left(R_{\text {Max }}-R_{\text {Min }}\right) \cos ^{2} \Theta_{c} \\
& R_{\text {Max }}=0.318 \mathrm{E}^{3 / 2}
\end{aligned}
$$

Where $\mathbf{R}_{\text {max }}$ is the range of $\boldsymbol{\alpha}$ - Particle in air. $\mathbf{E}:$ (energy) in $\mathrm{MeV}$ 
$\mathbf{R}_{\text {min }}$ was put equal to zero $\boldsymbol{\theta}_{\mathbf{c}}=35^{\circ}$ is the average value of critical angle for CR -39 detectors (Barillon et al., 1993) .

The effective Radium content of the solid sample can be calculated from the formula (Azam,et al,1995).

$\mathrm{C}_{\mathrm{Ra}}\left(\mathrm{Bq} \cdot \mathrm{kg}^{-1}\right)=\left(\frac{\mathrm{P}}{\mathrm{K} . \mathrm{T}}\right)\left(\frac{\mathrm{h} \cdot \mathrm{A}}{\mathrm{M}}\right)$

Where :

$\mathrm{M}:$ is the mass of the solid sample in $\mathrm{kg}$.

$\mathrm{A}:$ is the area of the cross-section of the tube in $\mathrm{m}^{2}$.

$\mathrm{h}$ : is the length of the air space between the detector and the top of the solid sample in meters .

\section{RESULTS AND DISCUSSION}

Table (1) presents the background-corrected track density $(\boldsymbol{\rho})$, radon concentration and also the calculated values of the effective radium content of four samples of coffee powder under study. The errors shown are due to track counting statistics . It is evident from table (1), that the effective Radon content for coffee samples vary between $(36.6$ $\pm 1.3)$ Bq. $\mathrm{m}^{-3}$ for Brazilian coffee and $(180.5 \pm 3.6)$ Bq. $\mathrm{m}^{-3}$ for Indian coffee .

Table 1: Radon and Radium content in coffee samples

\begin{tabular}{|c|l|c|c|c|c|}
\hline S .No. & \multicolumn{1}{|c|}{$\begin{array}{c}\text { Origin Of } \\
\text { coffee }\end{array}$} & $\begin{array}{c}\text { Track } \\
\text { Density } \\
\text { (Track.cm) }^{-2}\end{array}$ & $\begin{array}{c}\text { Radon } \\
\text { Content } \\
\text { (Bq.m) }^{-3}\end{array}$ & $\begin{array}{c}\text { Effective } \\
\text { Radium } \\
\text { Content } \\
\text { (Bq.kg) }^{-1}\end{array}$ & $\begin{array}{c}\text { Effective } \\
\text { Radium } \\
\text { Content } \\
\text { (pCi.kg) }\end{array}$ \\
\hline 1. & Indian & $695 \pm 14^{*}$ & $180.5 \pm 3.6^{*}$ & 0.0925 & 2.5 \\
\hline 2. & Yamanian & $359 \pm 11^{*}$ & $93.25 \pm 2.8^{*}$ & 0.0479 & 1.29 \\
\hline 3. & Kenian & $279 \pm 9^{*}$ & $72.5 \pm 2.3^{*}$ & 0.0372 & 1.0 \\
\hline 4. & Barazilian & $141 \pm 5^{*}$ & $36.6 \pm 1.3^{*}$ & 0.0185 & 0.5 \\
\hline
\end{tabular}

$* \sigma=\sqrt{\frac{\sum(n-n i)^{2}}{n-1}}$

The Effective radium content is minimum $\left(0.5 \mathrm{pCi} . \mathrm{kg}^{-1}\right)$ For Brazilian Coffee and

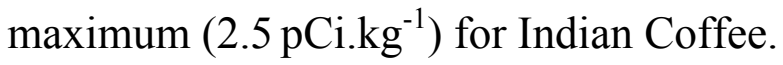

Although no measurements of radon and radium contents in Coffee is available in literature, there had been some measurements for tea and tobacco samples and some building materials presented in Table (2) . 
Table 2: Radon and Radium content in different Materials

\begin{tabular}{|c|c|c|c|}
\hline Reference & Material & $\begin{array}{c}\text { Radon content } \\
\left(\mathbf{B q . m}^{-3} \mathbf{)}\right.\end{array}$ & $\begin{array}{c}\text { Radium content } \\
\mathbf{( B q . k g}^{-1} \mathbf{)}\end{array}$ \\
\hline Khan et al.,1988 & Tea & $27-37$ & \\
\hline Al-Gibourie,1999 & Tea & $23.77-51.3$ & $0.0512-0.111$ \\
\hline Azam et al.,1995 & Building Materials & & $0.5-3013$ \\
\hline $\begin{array}{c}\text { Khalil and Abdul }- \\
\text { Maseeh,2001 }\end{array}$ & Tobacco & $72-123$ & \\
\hline Present Study & Coffee & $36.3-180.5$ & $0.0185-0.0925$ \\
\hline
\end{tabular}

The radon and radium contents of coffee are quite similar to those of tea and tobacco.

A study of radon exhalation rates from different food samples is important for understanding the relative contributions of individual materials to the total radon content found inside the body. A relatively high value of radium content in different food samples in due to the naturally occurring of uranium isotopes in soil. All the obtained values were within the natural limits, where the annual dose limits for public equal to 400 bq. $\mathrm{m}^{-3}$ given by the international commission on radiological protection (ICRP, 1966).

\section{REFERENCES}

$\mathrm{Al}$ - Goubory, M., 1999. Determination of ${ }^{222} \mathrm{Rn}$ in Different Types of Tea. M.Sc. Thesis, College of Science, Mosul University .

Azam A.; Naqvi A . H. and Srivastava D.S., 1995. Radium Concentration and Radon Exhalation Measurements Using LR-115 Type II Plastic Track Detectors . Nucl . Geophysics, Vol . 9 , No 6, 653p.

Barillon R. Klein D .; Chambaudet A . and Devllard C., 1993. Comparison Of Effectiveness of Three Radon Detectors ( LR-115, CR-39 and Silicon Diode Pin ) Placed in a Cylindrical Device - Theory and Experimental Techniques . Nucl . Tracks Radiation Measurements, Vol.22, No 1, 281p .

Cember H., 1978. Introduction to Health Physics . Pergamon Press, ICRP Publication 7 , Pergamon Press(1966).

Kaplan I., 1963. Nuclear Physics . Addison -Wesley Publishing Company, Inc.

Khalil M.A. and Abdul -Maseeh A.M.,2001. Determination of Radon ${ }^{222} \mathrm{RN}$ Concentration and Radioactivity in Different Types of Domestic and Foreign Tobacco . Al-Raffiden Journal, Vol.12, 146p.

Khan A.J.; Sharma K. C.; Varshney A.K.; Prasad R., and Tyagi R.K.,1988. Radon Estimation in some Indian Tobacco, Tea and Tooth Powder Using CR-39 Nuclsar Track Detector. Radiation Environ .Biophysics, Vol.27, 233p.

Naom H.A, 2002. Determining of Uranium in Tooth Past by Using CR-39 Detector. M.Sc. Thesis, College of Science, Mosul University.

Nikezic D.; Baixeras C. and Kostic D.,1996. Sensitivity Determination and Optimization of a Cylindrical Diffusion Chamber, for Radon Measurements, with a CR-39 Detector. Nuclear Instruments and Methods in Physics Research A., Vol.373, 290p. 